\title{
HISTORICAL AND POLITICAL BACKGROUND OF FEDERAL HEALTH CARE LEGISLATION
}

\author{
Carleton B. Chapman* and John M. Talmadge $†$
}

The concept of a right to health, to some extent guaranteed to citizens by government, has within it heavy political as well as social overtones. The demand to "keep politics out of health" is a futile one, and it is now heard with less and less frequency.

The politics of health have evolved in the United States by fits and starts. The concern of government has gradually moved from the general health of millions"public" health-to a growing and increasingly pressing awareness of the unmet health needs of individuals. ${ }^{1}$ Specific political settings have of course always conditioned the content and effect of health legislation, especially at the federal level, and the organized health professions, notably the AMA, have availed themselves of those settings as well as they were able to support their own point of view before legislators and voters. The legislative end results have been determined by a mix of pragmatism, political opportunism, the pressure of special interest groups, health crises, technologic factors, and genuine concern for the public good.

\section{I}

\section{The First Federal Health Laws}

Early federal action in the health field was almost entirely pragmatic, and much of it was brought about by the menace of recurrent epidemics of yellow fever. It was George Washington who asked Congress to pass the first federal health law, a purely utilitarian proposal to allow the Chief Executive to convene Congress outside the capital if epidemic disease should threaten the members. Washington's move occurred when the great yellow fever epidemic of 1793 forced the entire government to flee from Philadelphia. Washington himself left in September and found it next to impossible to run the government by correspondence from Mount Vernon. His request was so obviously sensible that it stirred virtually no opposition, and Congress quickly obliged. $^{2}$

It was quite otherwise when Congress brought a federal quarantine proposal under debate in 1796 . The debate on this matter in the House dealt with the powers of the central government to impose the quarantine. Representative Lyman, arguing

* Dean, Dartmouth Medical School, Hanover, New Hampshire.

† A.B. $x 969$, Dartmouth College; Ziegler Foundation Fellow, 1969-70, Duke Medical School, Durham, North Carolina.

1 The reference throughout is to health legislation as it affects the civilian population. Acts of Congress concerning the health of military personnel, merchant seamen, and special wards of the government are not directly relevant to the present discussion.

${ }^{2}$ Act of April 3, I794, ch. I7, I Stat. 353. 
for exclusive state power, maintained that the states" "right to preserve health and life was inalienable" and paramount to the central government's power over commerce; ${ }^{3}$ indirectly at least, Lyman was underscoring government's responsibility for the health of its citizens, and recent endorsements of a right to health reflect further growth of this governmental commitment. In the 1796 debates, virtually no one questioned the right (or responsibility) of government to protect the health of the population from the ravages of yellow fever; the only real question had to do with which level of government should enact and enforce quarantine measures. ${ }^{4}$

The debate split cleanly along Federalist and Antifederalist lines. The venemous controversy between Alexander Hamilton, Secretary of the Treasury, and Thomas Jefferson, Secretary of State, was beginning by I792 to create a two-party system in the new nation. Hamilton's federalist party advocated strong central government; Jefferson's antifederalists solidly backed states' rights and agrarian interests. The House, in 7796 , was made up of fifty-six antifederalists (of whom Lyman was one) and forty-nine federalists. With regard to quarantine, the federalists lost the battle. The law that finally passed assigned quarantine authority to the states and placed the central government in a permissive, supporting role. ${ }^{5}$

It was a politically determined precedent of fundamental importance. Nor did Jefferson's election to the presidency in I8or, which spelled the doom of the federalist cause in many respects, affect the precedent: quarantine authority remained firmly in the hands of the states.

But Jefferson himself was not always consistent with regard to states' rights in matters of health. After he retired from the presidency, he became interested in Jenner's method of preventing smallpox by cowpox vaccination, which had been introduced in Britain in 1796 . One of the problems at the time was the production of effective cowpox vaccine, and when a bill was introduced into Congress during Madison's administration, requiring the federal government to guarantee and distribute effective vaccine free of charge, Jefferson was in favor of it. Under the proposal, which became law on February $27,1813,{ }^{6}$ the federal government appointed vaccine agents and dispatched cowpox vaccine to any citizen who requested it. The implications were clear: not only did the central government take on a massive public health responsibility; it also was authorized to deal directly with the individual citizen, at taxpayers' expense, to protect him from one of the major killer-diseases of the time.

The law remained in force for nine years, and its constitutionality was never questioned. Conceivably, it might still be on the books had not a federal vaccine agent sent smallpox, instead of cowpox, vaccine to North Carolina by mistake. Several deaths resulted, and Congress, alarmed by the resulting outcry, took the

\footnotetext{
${ }^{3} 5$ ANNAls of Cong. 1354 (1796).

Id. at 1347-59.

'Act of May 27, I796, ch. 3I, I Stat. 474.

'Act of Feb. 27, 1813, ch. 37, 2 Stat. 806.
} 
matter under consideration. ${ }^{7}$ It concluded that vaccination had best be in the hands of the states and repealed the law in I823 during Monroe's "era of good feeling."

The entire episode was a curious one politically. It was, in fact, an admission by the Jeffersonians that certain health measures might be assigned, pro bono publico, to the central government, but neither the residue of the federalist movement nor its successors ever seem to have made political capital of it.

\section{II}

\section{John Marshall Settles the Matrer}

But the quarantine precedent of 1796 was soon to receive resounding support from the Supreme Court. It came in the form of a famous (and prodigiously long) decision written in I824 by John Marshall. An extraordinarily astute jurist and a last-minute federalist appointment to the Court, Marshall (and his Court) had under consideration the question of interstate commerce. It had been precipitated when the State of New York granted an exclusive franchise for steam navigation within the state to Robert Fulton and Robert Livingston. The matter of quarantine had been introduced into the argument to support New York's action in awarding the franchise; but Marshall was unimpressed. "Inspection laws, quarantine laws, health laws of every description," he wrote, are all part of an "immense mass of legislation" which the Constitution does not assign to the central government and which, therefore, remain in the hands of the states. ${ }^{9}$ But, the Court's ruling ran, the power to enact such laws does not derive from the power to regulate commerce, a power specifically assigned by the Constitution to the central government. And if state quarantine laws should interfere with "the laws of the United States, made for the regulation of commerce .... [the] Congress may control the state laws ...."10

Marshall's interpretation of the Constitution was a strict and far-reaching one: regulation of interstate and foreign commerce was specifically assigned to the Congress by article I, section 8 , subsection 3 ; health matters were not specifically assigned and therefore belonged to the states under the tenth amendment.

This, in any case, was the effect of the decision. But Marshall had left a loophole. Referring to "that immense mass of legislation ... not surrendered to the general [federal] government," he added that "[i]f the legislative power of the Union can reach them, it must for national purposes."11 His meaning is, perhaps intentionally, obscure, but he may have been doing nothing more than taking into account the possibility that the nation might one day be faced with a massive threat to health, possibly a pandemic, which would make use of federal resources mandatory.

\footnotetext{
${ }^{7}$ H.R. REP. No. 93, I7th Cong., Ist Sess. (1822).

${ }^{8}$ Act of May 4, 1822, ch. 50, 3 Stat. 677 .

${ }^{9}$ Gibbons v. Ogden, 22 U.S. (9 Wheat.) r, 203 (1824).

${ }^{10} \mathrm{Id}$. at 206.

${ }^{11}$ Id. at 203 (emphasis added).
} 
III

\section{The Last Quarter of the Nineteenth Century}

There matters rested, insofar as federal legislation affecting the health of the general public was concerned, for many decades. From the time of the Jackson administration (I829-37) to the outbreak of the Civil War, the nation was almost totally preoccupied with expanding its boundaries and its communications. Considerations of the social obligations of government found no place in Congressional debate of the period, although toward the latter part of it there was some activity of the sort at the state level, notably in Massachusetts. ${ }^{12}$

The post-Civil-War period was one of industrial expansion and conservative political action. The American Medical Association, founded in 1847 , had taken no formal political stand, but its actions before and after the Civil War show unmistakably that it approved of government intervention, federal and state, in the field of public health. It went on record as favoring federal quarantine authority and a federal health department. ${ }^{13}$ But, said its leadership, medical care for the individual is the medical profession's inviolate territory and obligation. ${ }^{14}$ Even so, the Association was, and for many years remained, well in advance of the federal government with regard to the health interests of the nation.

In 1878 , crisis finally goaded the Congress to action. It came in the form of another yellow fever epidemic beginning in early summer in New Orleans and moving rapidly up the Mississippi River valley. Before the epidemic had run its course, twenty to thirty thousand had died and the country was in an uproar. Congress reacted, while the epidemic was in progress, by passing new quarantine actions that still carefully avoided encroachment on states' rights. But in $x 879$, following a Senate select committee report, a bill to create a National Board of Health, with supervisory quarantine authority, was introduced and became law on March $3 .{ }^{15} \mathrm{~A}$ second bill, designed to clarify and strengthen the Board's authority, was introduced soon after. ${ }^{16}$ It precipitated debate in the House focusing once again on the states' rights issue, on which ground most southern Congressmen opposed the measure. The debate was heated and went on much longer than the comparable one in $x 796$. Representative Omar D. Conger of Michigan finally went straight to the point:

\footnotetext{
${ }^{12}$ In I850 a Massachusetts Sanitary Commission said that "public authority and public administration" should protect the citizens from identifiable health hazards. Comamissioners of the SANITARY SURvey, Report of a General Plan for the Promotion of Public and Personal Heastri (1850). The report led finaliy to the establishment of the Massachusetts Board of Health in $x 869$.

138 Trans. A.M.A. 37-38 (I855) (minutes of the 8th Annual Meeting of the AMA, held at Philadelphia, May I-4, I855).

14 29 Trans. A.M.A. III ( 1878 ) (Address of T.G. Richardson, M.D., at the 29th Annual Meeting of the AMA, held at Buffalo, June $4-7,1878)$.

${ }^{16}$ Act of March 3, I879, ch. 202, 20 Stat. 484.

${ }^{10}$ Act of June 2, I879, ch. Ir, 2I Stat. 5 .
} 
Show me a southern State-rights democrat on this floor . . . and I will show you the man whose conscience has been relieved from all obligation as a State-rights man if he had a harbor to build within his district, or a river to deepen and improve. ${ }^{17}$

It was the old federalist-antifederalist political argument all over again except that sectional alignments were by now somewhat altered. Yet this time the advocates of strong federal quaranine authority carried the field. The bill passed and the National Board set to work, but under great difficulties. Within a year it was under heavy fire from state authorities (notably those from Louisiana), who resented its intrusion into their affairs, and there was bitter opposition, led by the Marine Hospital Service, from within the federal government itself. The end result was that the law setting up the Board, which had been given four years to run, was allowed by Congress to expire. States' rights were still a treacherous political issue, and, in addition, memories of the yellow fever epidemic of 1878 were beginning to dim.

But the National Board law was the closest Congress has ever come to setting up a federal department of health answerable ultimately to the President. The Marine Hospital Service, later to become the United States Public Health Service, was an arm of the Treasury Department, and, although it administered federal quarantine statutes, its role vis-à-vis state authority was largely advisory.

It is ironic that the series of events that finally brought about the transfer of quarantine authority to the federal government was set in motion by the State of Louisiana. A law was passed by that state in I882 requiring that ships passing up the Mississippi River submit to inspection at a quarantine station near the mouth of the river. Each ship was required to pay a "service" tax of $\$ 30$. A steamship company, alleging that the tax was actually a tonnage tax, took issue, and the matter finally reached the Supreme Court in I886. The Court, for which Justice Samuel F. Miller spoke, ruled in favor of Louisiana. But it also virtually invited Congress to pass an effective quarantine law:

[I]t may be conceded [said the Court] that whenever Congress shall undertake to provide for the commercial cities . . . a general system of quarantine, or shall confine the execution ... of such a system to a National Board of Health ... all State laws on the subject will be abrogated, at least so far as the two are inconsistent. But, until this is done, the laws of the State on the subject are valid.18

Louisiana's victory thus ultimately proved to be a pyrrhic one.

But Congress was in no hurry to act: members of Congress, unlike Supreme Court justices, had to run for office. Not until early r893, in the last days of Benjamin Harrison's administration, did Congress move. It was by then safer to do so, largely because of a new threat of epidemic disease from abroad. In the late summer of

\footnotetext{
${ }^{17} 9$ Cong. Rec. 1647 (1879) (remarks of Representative Conger).

${ }^{18}$ Morgan's S.S. Co. v. Louisiana Bd. of Health, II8 U.S. 455,464 (I886).
} 
1892, four ships arrived in New York harbor from Hamburg with cholera aboard, all among steerage passengers. Each of the ships had had deaths at sea from the disease. ${ }^{19}$ The press sounded the national alarm and, before the year was out, the demand for a federal quarantine authority was widespread. The New York Times did its bit by quoting press opinion from all sections of the country during December I892 and January of the next year. A Savannah paper said that the demand was not a partisan one but came from the people. Some papers hit the states' rights issue head on. The Chicago Tribune, for example, wryly commented, "The cholera will make this country much sicker than an infraction of the Jeffersonian ideas will, ${ }^{, 20}$ and the Hartford Post twitted the antifederalist holdouts with the following:

The gentlemen of Texas and Louisiana propose if they die of cholera to be able to thank the Almighty that they caught it in a constitutional way, strictly Jeffersonian, and with regard for States' rights. ${ }^{21}$

New York, as it turned out, had no cholera epidemic, but the scare, and the nation's reaction to it, were enough to overcome Congress's fear of moving in on the rights of the states with regard to quarantine. The then current Populist movement may also have had something to do with it. In Hofstadter's view, "Populism was the first modern political movement ... to insist that the federal government has some responsibility for the common weal ...."22 Although the Populist Party never included a health plank in its platform, it unmistakably identified itself with certain types of social and political reform, some of which later became law even though the party itself had disappeared. In the mid-r8gos its influence was strong enough to enable it to poll thirty or more per cent of the popular vote in twelve states. $^{23}$

In any case, a bill introduced by Representative Isidore Rayner of Maryland in late $18 \mathrm{~g}^{24}$ finally passed, but only after lively debate. The main opposition, following undiluted antifederalist lines, came from representatives from Alabama, Texas, and Louisiana, one of whom (Oates of Alabama) said, "[I]t is desirable to keep out an invasion of cholera, and also of anarchists and communists.... [I]t is right and proper for Congress to do whatsoever it has authority to do to these ends."25 But he then went on to say that Congress has no jurisdiction to enact quarantine or health laws overruling the laws of the states. A few weeks later, when the bill as amended by the Senate came back to the House, Representatives Kilgore and Antony of Texas made a temporary shambles of the House session by various parliamentary ruses, ${ }^{26}$

\footnotetext{
${ }^{10}$ Cholera in New York Bay, 36 HARPER's WeERLY 906 (1892).

${ }^{20}$ National Quarantine, N.Y. Times, Jan. I6, I893, at 4 .

${ }^{21}$ National Quarantine, N.Y. Times, Jan. 30, I893, at 4.

20 R. Hofstadter, The Age of Reford 6I (r955).

${ }^{23}$ See generally J. Hicks, The Popusist Revolt (I93I).

24 24 CoNg. REC. 21 ( 1892 ).

${ }^{25} I d$. at 755 ( 1893$)$.

${ }^{30}$ Id. at $1337-38$.
} 
but, in the end, the House accepted the Senate amendment and the bill became law on February I5, I893. ${ }^{27}$ Though amended since, it still stands. ${ }^{28}$

\section{IV}

\section{The Progressive Era: Reaction and Counterreaction}

The federal government finally took over quarantine authority, partly because public fear of epidemics made it politically feasible to do so, and partly because the political climate itself was changing. The quarantine law of 1893 has received relatively little attention, largely because it bore on the health of the millions, not on that of the individual. But it was a major, if rather subtle, turning point in the evolution of federal and public attitudes toward the obligation of the central government in matters of health. Conservatives of the period were not altogether wrong when they said it was a foot in the door.

But the rise of the Progressives, roughly paralleling the advance to respectability and influence of the Socialist Party, focused the attention of the nation on government's obligation to the individual in general. Universal health insurance was singled out as a major objective, especially by the American Association for Labor Legislation, which, in 1916 , drafted a model insurance law to be administered on a compulsory basis by the states. ${ }^{29}$ In the same year Meyer London, Socialist Congressman from New York's East Side, introduced a House Joint Resolution calling for a federal commission to draft a health insurance bill. ${ }^{30}$ A health insurance plank had been included in the Progressive Party platform in $1912,{ }^{31}$ and Woodrow Wilson, in his first inaugural address early the next year, served unmistakable notice that the federal government ought to safeguard the nation's health. ${ }^{32}$

But it all came to very little at the time, owing largely to the immense wave of conservatism and anti-Bolshevist hysteria that swept the country in the last years of World War I and the period immediately following. New and oppressive alien and sedition laws, reminiscent of those of 1798 , were passed, and, in Ghent's words,

Within a year after the armistice we were in the midst of a tide of reaction which threatened to sweep away every social achievement gained during ... the two previous decades. By that time or a bit later the whole fabric of social control had been rent and ravelled. ${ }^{33}$

${ }^{27}$ Act of Feb. 15, I893, ch. Ir4, 27 Stat. 449.

${ }^{28}$ Act of July I, I944, ch. 373, tit. III, $\$ \S 36 \mathrm{I}-64,366,368,58$ Stat. 703-06 (codified at 42 U.S.C. $\$ 264-67,269,271(1964))$.

${ }^{20}$ Health Instrance: Tentative Draft of an Act, 6 AM. LAB. LEg. REv. 239 (1916).

${ }^{30}$ H.R.J. Res. I59, 64th Cong., Ist Sess., 53 Cong. REc. 2856 (I9r6).

s1 "The protection of home life against the hazards of sickness, irregular employment and old age through the adoption of a system of social insurance . . . A A Contract with the People: Platrorm of THE PROGRessive PARTY 5 (I9I2).

32 I Public Papers of Woodrow Wilson: The New Democract 4 (R. Baker \& W. Dodd eds. I926).

${ }^{33}$ W. Ghent, The Reds Bring Reaction 3 (1923). 
The model health insurance bill was introduced into several state legislatures (including New York's) shortly after the war but was enacted by none. Toward the end of the Progressive Era, Ernst Freund, Professor of Law at the University of Chicago, gave the proponents of health insurance legislation sage, if belated, political advice. He thought constitutional bases for such action, at least at the state level, could be found. But he added,

[L]et the advocates of health insurance agree upon a minimum program and urge the adoption of that. The well known expansive tendencies of relief legislation may be relied upon to take care of the future. ${ }^{34}$

The American Medical Association, which had participated in drafting the Model Bill and which had, from IgI5 to I9I9, shown active interest in health insurance legislation, now vigorously rejected every trace of its own Progressive Era. In I920 and I922, its House of Delegates passed resolutions which placed organized medicine in implacable opposition to federal health legislation in general-if it was for the benefit of the individual citizen. One of the actions specifically opposed federal compulsory health insurance but made no mention of voluntary insurance. ${ }^{35}$ The other defined state medicine as "any form of medical treatment provided, conducted, controlled or subsidized by the federal or any state government, or municipality ...."36 The AMA was opposed to all forms of state medicine coming within the definition except services to military personnel and a few other special groups. ${ }^{37}$ Neither action has ever been significantly modified.

From Harding to Hoover the federal government showed little interest in health except that of veterans. One further exception was the Sheppard-Towner Act, passed early in Harding's administration, that provided federal grants to states "for the promotion of the welfare and hygiene of maternity and infancy."38 Under its new policies, the bill had been unsuccessfully opposed by the AMA. ${ }^{39}$ The Democratic platform for 1928 included a health plank of vague content, ${ }^{40}$ but it seems to have won their candidate (Al Smith) very few votes.

\footnotetext{
${ }^{36}$ Freund, Constitutional and Legal Aspects of Health Insurance, 44 Proc. NAr'L CoNF. Soc. Worr 553,558 (1917).

${ }^{36} 74$ J.A.M.A. I3Ig (1920) (minutes of the 7Ist Annual Session of the AMA, held at New Orleans, Apr. 26-30, 1920).

Bo 78 J.A.M.A. I7I5 (1922) (minutes of the $73 \mathrm{~d}$ Annual Session of the AMA, held at St. Louis, May 22-26, I922).

${ }^{87}$ Id.

${ }^{88}$ Act of Nov. 23, I921, ch. I35, 42 Stat. 224.

${ }^{80}$ Editorial, Federal Care of Maternity and Infancy: The Sheppard-Towner Bill, 76 J.A.M.A. 383 (I92I).

"O "The Democratic Party recognizes that not only the productive wealth of the Nation but its contentment and happiness depends upon the health of its citizens. It therefore pledges itself to enlarge the existing Bureau of Public Health and to do all things possible to stamp out communicable and contagious diseases . ..." Platform of the National Democratic Party, in Platforms of the National. Reputican and Democratic Parties: 1928, at 36 (i928).
} 


\section{Soctal Security and its Aftermath}

During the Great Depression, said Frederick Lewis Allen, there was "a lasting change ... in the attitude of the American people toward their economic and political institutions." ${ }^{\text {41 }}$ It might be more accurate to say that the Great Depression was a crisis of sufficient magnitude to bring some of the seeds sown by the Populists and Progressives from their dormant state.

In any case, the Social Security Law of 1935 was the first major legislative result. ${ }^{42}$ As originally introduced by Senator Wagner and Congressman Doughton, the bill contained one title that, in effect, was a revival of Meyer London's resolution of rgi6: it proposed a Social Insurance Board that was to make recommendations on "legislation and matters of administrative policy concerning old-age insurance, ..., health insurance, and related subjects." ${ }^{\text {43 }}$ But, owing largely to pressure from the AMA and to Roosevelt's fear that he might lose the whole social insurance package, the Social Insurance Board became the Social Security Board, and all reference to health was dropped. Thus altered, the bill passed the House with astonishing ease ( 372 yeas and thirty-three nays), ${ }^{44}$ and became law on August I4, I935.

That such a sweeping federal social action should invoke virtually no organized political opposition (except for that of the AMA to the health provision of the original bill) is perhaps a measure of the depth of the crisis the nation faced at the time. And when opposition did arise, it had the paradoxical effect of confirming the social security principle as a permanent part of American political and social life. The opposition was in the form of suits brought by employers against the Collector of Internal Revenue. They reached the Supreme Court in early I937 with the result that Mr. Justice Benjamin Cardozo wrote decisions that set the country on a new course. In Steward Machine Co. v. Davis, ${ }^{45}$ Cardozo cited the general welfare clause of the Constitution ${ }^{46}$ as the basis for upholding the Social Security Law, and, although neither Cardozo's decision nor the Constitution specifically mentions health, the inference was clear. Through Cardozo, the Court cleared up the confusion that had prevailed with regard to federal quarantine authority, which, to that time, had been thought to rest most solidly on the commerce clause. On the same day the Court, still speaking through Cardozo, said that title II of the Social Security Law is not in opposition to the tenth amendment and that Congress may indeed spend money to protect the general welfare. "Nor," said the Court, "is the concept of the

\footnotetext{
"Allen, Economic Security: A Look Back and a Look Ahead, in Economic Securitr for Americans 13 (Third American Assembly r954).

$\therefore$ Act of Aug. 14, 1935, ch. 53I, 49 Stat. 620.

${ }^{18}$ S. II30, 74th Cong., Ist Sess. (I935); see 79 Cong. Rec. 549, 55I (1935).

14 79 Cong. Rec. 6069-70 (1935).

4 3or U.S. 548 (1937).

10 "The Congress shall bave Power To lay and collect Taxes . . . to pay the Debts, and provide for the common Defence and general Welfare of the United States ...." U.S. Const. art. I, $\$ 8$.
} 
general welfare static. . . What is critical or urgent changes with the times." ${ }^{.47}$ And, " $[w]$ hen money is spent to promote the general welfare, the concept of welfare or the opposite is shaped by Congress, not the states." 48

From the constitutional point of view, the Cardozo decisions brought to an end the process that began with the Marshall decision in 1824 . But politically the effect was not quite so definitive. Health had become a respectable political topic, and, after the Cardozo decisions, no political party dared ignore it altogether. The concept of a right to health gradually lost its nineteenth century limitations and focused more and more on the individual's health needs, broadly defined, although the country was not yet ready for comprehensive federal health legislation. The rising costs of health care may have been a factor in this change of emphasis. In the nineteenth century, relatively few of the nation's citizens had access to hospitals and specialists. Laboratory tests were virtually unknown; the $\mathrm{x}$-ray was discovered by Roentgen in I8g6 but came into general medical use only after World War I; the electrocardiograph dates from I9I2 but was not in general use until after I930. By the mid-r930s utilization of hospitals, which were formerly turned to only in case of terminal illness or major surgery (if at all), was increasing rapidly. Medical diagnosis and treatment had gone far beyond the stethoscope and epsom salts stage. The general practitioner's black bag no longer contained all that patients needed and were beginning to demand.

\section{VI}

\section{The Post-Worid-War-II Scene}

Although the health theme was expunged from the original Social Security proposal, it was never very far from Senator Robert Wagner's mind. Drawing on analyses that had been carried out to support the original Social Security bill, he introduced amendments relative to health in 1939 but without success. The threat of war in Europe and opposition by the AMA were obstacles too formidable to overcome. But in 1943 the battle was really joined. In that year Senators Wagner and Murray and Congressman Dingell introduced their first proposal for federal compulsory health insurance. They reintroduced such proposals in 1945, 1947, and 1949, precipitating one of the major political battles of President Truman's administration. The bills all failed, but the intensity and bitterness of the fights over them were themselves evidence of the growing political importance of the health question.

The AMA's opposition was based primarily on its policies of the rg2os and led it, at great cost, into the first of its major national political campaigns. Whether the electorate was ready to accept federally-backed compulsory health insurance in the years immediately after World War II is a matter for conjecture. But the weight of

\footnotetext{
${ }^{47}$ Helvering v. Davis, 30I U.S. 6r9, 64r (1937).

${ }^{18}$ Id. at 645 .
} 
Roosevelt's words in his State of the Union message on January II, 1944, was such as to identify permanently the right to health with other fundamental rights in the American political system: ${ }^{49}$ in that address he equated "the right to adequate medical care and the opportunity to achieve and enjoy good health" with fundamental social and political rights in his "Economic Bill of Rights."

The return of the Republicans to office in 1952 reassured conservatives with regard to the threat of comprehensive federal health legislation. President Eisenhower had publicly announced his opposition to compulsory health insurance, but, even so, his administration could not completely ignore the health insurance issue. It proposed a reinsurance system, leaving health insurance voluntary, ${ }^{61}$ but the mood of Congress was conservative: nothing happened.

With that, the emphasis on federal guarantees of the individual's right to health, far from dying, merely shifted to a particularly needy group, the aged. The battle over federally backed health insurance for the aged stretched across three administrations and culminated with the passage of Medicare-Medicaid legislation in 1965 . Its most dramatic moment came in May Ig62, when President Kennedy addressed an overflow crowd at Madison Square Garden, urging support for the then-pending King-Anderson bill. The AMA countered by staging its own program, televised the next night, immediately following the President's address. ${ }^{52}$ The issue, in the eyes of the AMA, was still basically one of states' rights. It had favored the Kerr-Mills bill of Ig60, which assisted the aged to obtain health care through federal grants to the states $^{53}$ whereas the King-Anderson bill would have extended benefits to the aged through the Social Security mechanism.

The King-Anderson proposal went down to defeat in $196 \mathrm{I}$ although it never came, as such, to a floor vote. ${ }^{54}$ Still the question would not die. The prospect of providing for the health of the aged by legislative means was a powerful political issue, and the essence of the King-Anderson proposal was reintroduced in 1964. The AMA countered with an imaginative proposal of its own, more liberal in its benefits than the King-Anderson bill but designed to hold federal authority at a minimum. The final result was a classic of political maneuvering in which the Johnson administration got more than it had originally asked and the AMA failed wholly in its effort to establish administrative authority over the system at the state level. ${ }^{\text {t5 }}$ The

\footnotetext{
${ }^{\circ 9}$ Message from the President of the United States on the State of the Union, H.R. Doc. No. 377, 78 th Cong., 2d Sess., in 90 CoNG. Rec. 55 (1944).

${ }^{80}$ go CONG. REC. at 57 .

51 156 J.A.M.A. I506-08 (1954) (Address of HEW Secretary Oveta Culp Hobby before the House of Delegates of the AMA, Miami, Florida, Nov. 29, I954).

${ }^{52}$ N.Y. Times, May 22, 1962, at I, col. 2.

${ }^{63}$ Social Security Amendments of I960, Pub. L. No. 86-778, tit. VI, $\$ \$ 601$ ef seq., 74 Stat. 987, amending 42 U.S.C. $\$ \$ 30 \mathrm{r}-04,306$ (1958).

"H.R. 4222, 87th Cong., Ist Sess. (I96I); see I07 Cong. REc. 2135-36 (I96r) (referred to the House Committee on Ways and Means).

${ }^{55}$ The whole process, including the critical role played by Congressman Wilbur Mills, is described in
} 
law as passed ${ }^{56}$ not only provided voluntary health insurance for the aged under Social Security; it also included a "sleeper" title (XIX) that extended health benefits, via the states, to the medically indigent regardless of age.

A president of the AMA attributed the ultimate defeat of his organization on the Medicare issue to the assassination of President Kennedy. On the evening before that event (November 2I, I963), according to outgoing president Donovan Ward, AMA spokesmen had just completed their testimony in Washington against the Medicare proposal. At that moment, he claimed "we were on the way to the most resounding legislative victory in our history as an organization." Johnson, beholden (according to Ward) to labor and liberal forces, changed all that.

In some measure Dr. Ward may have been right. But the state-federal issue concerning authority in health matters had been settled at the federal level long since, and that fact has had the effect, since the I920s, of putting the AMA in the position of a rear-guard unit. Medicare-Medicaid was passed, despite conservative opposition, and President Johnson journeyed, fittingly enough, to Independence, Missouri, to sign the bill into law in Harry 'Truman's presence. It was the culmination of a sociopolitical struggle that began in the Progressive Era and that had waxed and waned since World War I. The new law represented the creation of a national health system for two important segments of the civilian population. With its passage the federal government had at last directly guaranteed the right to health of broad classes of private American citizens.

Medicare was unquestionably a major watershed in the evolution of federal health policy. Once it was passed, the Eighty-ninth Congress, to which President Johnson understandably (from his point of view) applied the adjective fabulous, went on to other health matters. Next to Medicare, its most significant actions were the Heart Disease, Cancer, and Stroke Amendments of $1965^{58}$ and the Comprehensive Health Planning and Public Health Services Amendments of $x 966.59$ The title of the former is deceptive; although focusing superficially on the major killer diseases, the act actually was a first step toward regionalization of the nation's health facilities and personnel. In effect, it invites the nation to regionalize itself and to disregard internal political boundaries (state, county, and municipal) in doing so. It deals, therefore, with one of the country's most delicate internal political issues-states' rights-and almost certainly would have died in Congress if, when introduced, it had borne the title now applied to it: Regional Medical Program. It is having the effect of stimulating fundamental dialogue and experiment pointing toward reorganization of the

P. Corning, The Evolution of Medicare (Social Security Admin., Office of Research and Statistics, Research Report No. 29, I969), and Meyers, Mr. Mills's Elder-Medi-Bettercare, Fontune, June I965, at $x 66$.

${ }^{60}$ Social Security Amendments of 1965 , Pub. L. No. 89-97, 79 Stat. 286.

${ }^{87}$ Remarks of the President, I93 J.A.M.A. 23 (1965).

${ }^{68}$ Pub. L. No. 89-239, 79 Stat. 926.

${ }^{\circ}$ Pub. L. No. 89-749, 80 Stat. II80. 
nation's health resources along logical lines. Its companion act, the Comprehensive Health Planning law, vests authority for broad planning in the individual state governments and, to date, has produced no dramatic results. The two laws are, in fact, badly designed and to some extent in conflict. But their day has not yet come; the experience gained as a direct result of their passage is bound to have a major effect on the design of the nation's future health system. Medicare and Medicaid are basically financing measures; the Regional Medical Program and Comprehensive Health Planning laws attack an equally fundamental but politically more difficult aspect of the health problem.

\section{ConcLusion}

No health legislation of basic importance has passed the Congress since 1966. (However, the pending-at this writing-Social Security amendments ${ }^{60}$ may prove to be significant in their impact if the concept of "health maintenance organizations" embodied therein proves workable in practice.) The last few years have been a time of regrouping and reassessment of the nation's health problem. The most heated controversies since I 966 have had to do with funding and impact of existing legislation, not with new proposals. Debates now beginning (which the AMA refers to as "the gathering storm"61) center on national health insurance. But there is increasing recognition, in and out of government, that national health insurance alone cannot guarantee the right to health in its present, broad sense. Other deficiencies, such as shortage and maldistribution of health personnel and facilities will also have to be taken into account.

Health insurance proposals now under discussion approach these latter issues in varying degrees. One of them is basically a voluntary financing (insurance) proposal and largely reflects AMA concepts. Another, introduced in Congress on August 27, $1970{ }^{62}$ by Senator Edward Kennedy and fourteen other Senators, takes its origins from the Model Bill of I9r6, various aspects of Social Security legislation, and the work of the late Walter Reuther's Committee for National Health Insurance. It, in effect, proposes a comprehensive national health service in the form of a "working partnership" between public and private sectors.

As these dramatically different proposals come under debate, political influences, based largely on the precedents of the past, will once again emerge. But the social polarization of the nation and the continuing political and economic effects of the war in Viet Nam have, in themselves, created a new and volatile political climate. Whether the new conditions will hasten, or retard, national health service legislation cannot be predicted with confidence.

\footnotetext{
${ }^{60}$ H.R. 17550, 9rst Cong., 2d Sess. (1970). Versions of this legislation were passed by both houses of the gIst Congress, but adjournment occurred before the differences could be resolved in conference. The proposal will be reintroduced in some form in the $92 \mathrm{~d}$ Congress.

${ }^{61}$ National Health Care-The Gathering Storm, Am. Med. News, Oct. 27, r969, at 1 .

${ }^{82}$ S. 4297, 91st Cong., 2d Sess. (1970); see I16 Conc. REc. S14,338 (daily ed. Aug. 27, 1970).
} 
But the time for such action is probably close at hand and the reasons are not far to seek: the major constitutional and political issues were settled with the federal quarantine law of 1893 , the Cardozo decisions, and the passage of Medicare-Medicaid. It remains now only to work out, hopefully on a pragmatic basis, the legislative and administrative details. 